\title{
Management of syphilitic hepatitis
}

\author{
Abdurrahman Kaya ${ }^{1 *}$ (D) and Sibel Yıldız Kaya ${ }^{2}$
}

\begin{abstract}
Syphilis is a sexuality transmitted disease caused by Treponema pallidum. Liver involvement is very rarely seen and occurs in the second phase of the disease. Syphilitic hepatitis generally is mild clinical condition and is characterized by high serum alkaline phosphatase level, often with normal or only slightly abnormal transaminases. The skin eruptions are classically diffuse, symmetric maculopapular rashes involving trunk and extremities. Involvement of palms and soles is a strong clue to the diagnosis of secondary syphilis. Therefore, syphilitic hepatitis should be included in the early differential diagnosis in patient with abnormal liver enzyme, especially increased alkaline phosphatase, and rashes involving palms and soles.
\end{abstract}

Keywords: Syphilis, Rash, Liver enzyme

\section{Dear editor,}

We have read with great interest the manuscript entitled Syphilitic hepatitis: a case report and review of the literature [1]. It presented a case of syphilitic hepatitis $(\mathrm{SH})$ that had jaundice, rashes and abnormal hepatic enzyme level. However, we have some concern regarding the management of the patient.

\section{Discussion}

The diagnosis of the patient is clear and was confirmed with the combination of serology and liver biopsy but dermatology consultation was not performed despite unresolved rashes. $\mathrm{SH}$ is the component of the secondary syphilis that bacteria disseminate all over the body. It is characterized by high serum alkaline phosphatase level, often with normal or only slightly abnormal transaminases. In patients infected with human immunodeficiency virus, about $50 \%$ present with mixed enzyme pattern and in $13 \%$ only hepatocellular enzymes are elevated. The skin eruptions are classically diffuse,

This comment refers to the article available online at https://doi.org/10.1186/ s12876-019-1112-z

*Correspondence: dr.abdkaya@hotmail.com

${ }^{1}$ Department of Infectious Diseases, İstanbul Training and Research Hospital, Istanbul, Turkey

Full list of author information is available at the end of the article All authors meet the ICMJE authorship criteria symmetric maculopapular rashes involving trunk and extremities. Involvement of palms and soles is a strong clue to the diagnosis of secondary syphilis $[2,3]$. In this case, the palms and soles were also involved. Therefore, dermatology consultation could provide early diagnosis and prevent unnecessary invasive procedure such as liver biopsy. We thought liver biopsy was early performed.

Secondly, the authors performed genital examination on admission. However, after diagnosing syphilis, they did not state anything about his sexual history including time to unprotected sex and presence or absent of previous genital lesion such as chancre. Therefore, the detailed sexual history of the patient should have been taken.

Thirdly, a single dose of penicillin G benzathine (2.4 million units intramuscularly) is the standard regimen for early syphilis (primary, secondary and early latent). Generally, SH is a mild condition and well responds to the treatment [3-5]. No clinical data is available for more prolonged treatment. However, in this case, the patient was given penicillin $\mathrm{G}$ per week for successive 2 months.

\section{Conclusion}

SH is very rare condition that was often overlooked and seen in secondary stage of the disease. A single dose of penicillin $G$ benzathine is the standart treatment for $\mathrm{SH}$. SH should be included in the early differential diagnosis in patient with abnormal liver enzyme, especially 
increased alkaline phosphatase, and rashes involving palms and soles.

\section{Abbreviation}

SH: Syphilitic hepatitis.

\section{Acknowledgements}

Not applicable.

\section{Authors' contributions}

AK collected the data and prepared the manuscript and coordinated the study. SYK was responsible for final editing of the manuscript. All authors participated in writing and revising the manuscript. All authors have read and approved the final manuscript.

\section{Funding}

No funding was received for this report.

\section{Availability of data and materials}

Not applicable.

\section{Ethics approval and consent to participate}

Not applicable.

\section{Consent for publication}

Not applicable.

\section{Competing interests}

All authors declare that they have no competing interests.

\section{Author details}

${ }^{1}$ Department of Infectious Diseases, İstanbul Training and Research Hospital, Istanbul, Turkey. ${ }^{2}$ Infectious Diseases Unit, Sungurlu State Hospital, Çorum, Turkey.

Received: 3 February 2020 Accepted: 12 October 2020

Published online: 12 November 2020

\section{References}

1. Huang J, Lin S, Wang M, Wan B, Zhu Y. Syphilitic hepatitis: a case report and review of the literature. BMC Gastroenterol. 2019;19(1):191.

2. Pleimes $M$, Hartschuh W, Kutzner H, Enk AH, Hartmann M. Malignant syphilis with ocular involvement and organism-depleted lesions. Clin Infect Dis. 2009;48(1):83-5.

3. Hicks CB, Clement M. https://www.uptodate.com/contents/syphilis-treat ment-and-monitoring. Accessed 21 May 2018.

4. Young MF, Sanowski RA, Manne RA. Syphilitic hepatitis. J ClinGastroenterol. 1992;15:174-6.

5. Rubio-Tapia A, Hujoel IA, SmyrkTC, Poterucha JJ. Emerging secondary syphilis presenting as syphilitic hepatitis. Hepatology. 2017;65(6):2113-5.

\section{Publisher's Note}

Springer Nature remains neutral with regard to jurisdictional claims in published maps and institutional affiliations.
Ready to submit your research? Choose BMC and benefit from:

- fast, convenient online submission

- thorough peer review by experienced researchers in your field

- rapid publication on acceptance

- support for research data, including large and complex data types

- gold Open Access which fosters wider collaboration and increased citations

- maximum visibility for your research: over $100 \mathrm{M}$ website views per year

At BMC, research is always in progress.

Learn more biomedcentral.com/submissions 